\title{
The Influence of Human Capital on Economic Growth
}

\author{
Riyanto Wujarso \\ Sekolah Tinggi Ilmu Ekonomi Jayakarta, Jakarta, Indonesia \\ Email: riyanto.rw@gmail.com
}

\begin{abstract}
This research examines the effect of human capital on regional financial development in West Java Province from 2017 to 2019. This study's procedure employs a quantitative approach, and the data used is secondary data. Secondary evidence in this analysis comes from BPS data reporting. Panel regression with the GLS fixed-effect model approach was used as the research technique. The results of this study are the human capital variable, namely the level of education level. Based on the estimation results in this study, the education variable is considered the variable with the most dominant influence on economic growth. This research also provides suggestions to local governments so that there is a need for an increase in regional expenditure allocations for the education and health sectors to improve the workforce's quality so that they can have high productivity that can encourage financial growth.
\end{abstract}

Keywords: Human Capital, Economic Growth, Education Level, Health Level, Workforce.

\section{A. INTRODUCTION}

Development is a multifaceted phenomenon that involves shifts in societal systems, changes in people's attitudes toward life, and national institutions' changes. Changes in the pace of economic growth, income inequality reduction, and poverty reduction are both examples of development (Amann et al., 2006). Efforts to achieve development success can be achieved through several essential factors that must be met, and can be the key to economic development. The key to growth is divided into two categories: economic and social metrics. One of the metrics used in economic indicators is the rate of economic development (Camacho, 2015).

Economic growth is a significant predictor in evaluating an economy's success, especially when examining the economic change outcomes introduced by a country or region (Umiyati, 2014). If the output of goods and services improves from the previous year, the economy is growing. Economic growth demonstrates how economic development can produce increased revenue or social welfare within a given period. A rise in a country's or region's economic growth indicates that its or region's economy is doing well (Putri, 2015).

Along with fast economic development, both parties must pay more attention to human resources, one of the unique drivers of production. In the context of schooling, health, and inspiration, human capital is a deciding factor for social and individual growth, especially in an era of rising competition and a global economy replete with scientific advances (Woodhall). Human capital formation is necessary to improve labor standards, but it is not enough to learn from society, politics, and the economy. Overall, the system affects learning in school. 
Human capital can be defined into many meanings, but human capital has the purpose of knowledge, expertise, competence, and other characteristics of humans related to economic activity (Becker, 2009). Therefore, human capital must be treated as a factor of production equal to physical capital and separated from labor. According to Adam Smith, humans are the main factor that determines the prosperity of the nations. The reason is that nature (land) has no meaning if there are no clever human resources to cultivate it to be helpful. In other words, Human capital is a key to economic growth. Physical wealth is worthless without highquality human capital (Spengler, 1977).

So, in general, capital is a kind of money that is not physically visible, related to the knowledge and skills possessed by humans that can be obtained through school years or training, which helps the production of goods and services. In line with this definition, Four lines of human capital can also impact economic development, according to Kumar (2006) 1. The output feature as an input variable is applied to human resources. 2. The accumulation of human resources generates favorable externalities, which increase participant productivity. This results in endogenous development. 3. The accumulation of intellectual resources leads to increased creativity and R\&D. (R\&D). This results in endogenous growth.

Human capital accumulation can affect physical capital expenditure and have a second-order impact on growth output. According to Fleisher et al. (2010), human capital has a beneficial effect on production and product development in crossprovince studies. Human capital is commonly regarded as a critical determinant of competitiveness and economic development. However, recent data on jobs and growth in the EU have exposed some of the flaws in this conventional viewpoint. Human capital does not seem to guarantee economic prosperity in and of itself (Hanushek, 2013).

This study will assess the extent of the influence of human capital on the economy in West Java Province. In this study, West Java was chosen as the object of research because it has economic growth that is superior to the economic development of several other regions in specific years and is close to Jakarta's capital city as the financial center in Indonesia.

\section{B. METHOD}

This is a quantitative method of study. Quantitative analysis is a way of analyzing data that can be estimated or analyzed using mathematical analysis methods. Meanwhile, quantitative analysis, according to (Sugiyono 2011), is research that focuses on evaluating hypotheses by calculating research variables with numbers and interpreting results using statistical procedures, while according to Martono (2010), the quantitative approach is a research approach about data collected and expressed in the form of numbers and take the distance between the researcher and the object under study using formal, standardized and measuring instruments. The data source of this research comes from secondary data. Secondary data is information derived indirectly from the research object but from other 
sources, both oral and written. Data obtained from the Central Statistics Agency (BPS), namely data from 25 urban districts in West Java from 2017-2019. The variables that are operational research include economic growth as the dependent variable and education level, health level, and workforce as independent factors. The analysis tool used is panel regression with the GLS fixed-effect model method.

\section{RESULT AND DISCUSSION}

The estimation results of panel regression from the model with the dependent variable of economic growth, the independent variable level of education, level of health, labor force on economic growth are presented according to table 1 below:

\begin{tabular}{|l|c|c|c|c|}
\hline \multicolumn{1}{|c|}{ Variable } & Coefficient & Std. Error & t- statistics & Prob. \\
\hline Constant (C) & -4.475710 & 0.810260 & -5.535600 & 0.0000 \\
\hline Education (RLS) & 0.913128 & 0.152346 & 6.051285 & 0.0001 \\
\hline Health (AHH) & 0.754085 & 0.198896 & 3.873943 & 0.0001 \\
\hline Workforce (AK Diploma/S1) & 0.332211 & 0.036349 & 9.137963 & 0.0000 \\
\hline Adjusted R-squared & 0.783026 & & & \\
\hline F-statistic & 17.33327 & & & \\
\hline Prob. (F-statistic) & 0.000000 & & & \\
\hline
\end{tabular}

Source: Process

The dependent variable in the panel regression test results is Economic Growth Rate, and the independent variables are Education, Health, and Labor Force. The regression model centered on the findings of the initial review is: $Y=-4.476+$ $0.913 \mathrm{RLS}_{i t}+0.754 \mathrm{AHH}_{i t}+0.332 \mathrm{AKdiploma} / \mathrm{S1} 1_{i t}+u$

From the results of the regression equation above, it can be seen that the regression coefficient for the Education variable, which has a positive value of 0.913 , explains that if there is an increase in the Education variable by 1 unit, the Economic Growth Rate variable will rise by 0.913 percent. The Health variable's regression coefficient, which has a positive value of 0.754 , explains that if there is an increase in the Health variable by 1 unit, the value of the Economic Growth Rate variable will rise by 0.754 percent. The positive regression coefficient of the Labor Force variable of 0.332 explains that if there is an increase in the Workforce variable by 1 unit, the Economic Growth Rate variable's value will rise by 0.332 percent.

The determination coefficient $\left(R^{2}\right)$ basically measures the capacity of the model to describe variance in the dependent variable $(Y)$, while other variables are explained outside the model. In this analysis, the determination coefficient $\left(R^{2}\right)$ evaluate with the adjusted $R$ Square value the best regression model.

On the basis of the data, the modified value R Square is 0.783 or $78.3 \%$. The contribution to the economic growth variable thus is clarified by the variables of education, health, and the workers and the fixed impact of individual cities by 78.3 percent. In contrast, other variables or independent variables outside the regression equation explained the contribution of effect to other variables of the economic rate of growth by 21.7 percent.

The statistical test $\mathrm{F}$ is used to test the hypothesis of the independent variable (Xparallel)'s effect on the dependent variable Y (Economic Growth Rate). According to the findings, the $\mathrm{F}$ count is 17,333 with a magnitude of 0.000 . This estimated $\mathrm{F}$ 
value is more significant than the F table (2.653). Sig F (0.000), but less than 5\% (0.050), meaning that $\mathrm{H}_{1}$ is approved and $\mathrm{H}_{0}$ is refused, which means that together with the Education, Health, and Labor Force variables influence, significant to the Economic Growth Rate variable.

The $t$ statistical test is used to analyze the independent variable ( $X$ partial's) impact on the dependent variable (Economic Growth Rate). The independent variables that affect the dependent variable are as follows, according to the $t$-test results in table 1 , that the education variable with ( $t$ count) at a margin of error of 5 percent is 6.051 (more important than $t$ of table 1,973), which equates to a major positive impact on the economic rate of growth variable, or a meaning value of 0.001 (less than 5 per cent alpha or 0.05). Health variable with a t-value of 3.873 (greater than $\mathrm{t}$ table 1973) or a meaning value of 0.001 (less than $5 \%$ alpha or 0.05 ). This means that the health variable with a $5 \%$ error margin has a substantial positive effect on the rate variable for economic growth. Variable labor force with a t value of 9.137 , or a significance value of 0.000 (less than $5 \%$ alpha, 0.05), at an error level of $5 \%$, that means that the Labor Force indicator has a significant positive influence on the variable economic growth rate.

\section{Relationship between Education Level and Economic Growth}

Education is a basic form of investment in human resources in addition to investing in physical capital. Education is considered a necessary factor because education increases knowledge and increases job skills so that, in the end, it will increase work productivity. With a significance value of 0.001 , this study's calculation findings show that schooling has a significant and beneficial impact on economic development (smaller than alpha 5 percent or 0.05 ). This implies that it is consistent with the current hypotheses.

The findings of this analysis are consistent with the hypothesis. Based on evidence from many Asiedu Countries (2014), education has an essential and optimistic impact on the promotion of economic growth. Increasing education can increase capability and an essential means of raising "human capital" in the future. Improving education, in general, can also increase productivity and the ability to increase income (economy) which is higher both at present and in the future.

This study's findings further affirm Dwi Atmanti's (2005) empirical findings, which state that increasing investment in human capital through education directly raises labor productivity. An increase in the aggregate output indicates an increase in productivity. These findings strongly support the theory of endogenous growth, which emphasizes the importance of the government's role to increase human capital as indicated by increased productivity, where productivity becomes the motor of economic growth.

\section{Relationship between Health Level and Economic Growth}

For basic human needs, health is important. In order to improve the quality of human capital, improvements in the health sector are required. Rising health in the 
workforce participation would then increase the output of production and promote economic development. The effects of health status on economic growth show, based on calculations, that the degree of health has a positive and critical effect on economic growth.

The study results support Handayani et al. (2016), an observer who used panel analyzes to demonstrate that health has a substantial and statistically meaningful effect on economic growth, as calculated by life expectancy. A one-year increase in life expectancy would increase productivity by 4 percent, according to the survey. This indicates that an increase in health affects labor productivity directly; in other words, it trusts the idea that health is a form of human capital.

\section{The Relationship of the Labor Force to Economic Growth}

According to Tjiptoherijanto (2001), one of the sources of economic growth besides education and health levels is the workforce's growth. An increasing population will increase the workforce, and this increase allows a country to increase production so that economic growth increases. Todaro stated that population and job development have historically been seen as optimistic forces that drive economic growth. The number of jobs will rise as the population grows. In addition, an increase in the number of jobs means an increase in demand.

Meanwhile, increased population growth means that the domestic economy is growing in size. The study's estimated findings indicate that labor force variables determined by the number of workforce graduates of Diploma / S1 according to districts/cities in West Java from 2017 to 2019 have a favorable and essential effect on economic development. This indicates that the study's results are consistent with the current theory.

The findings in this study support previous research conducted by Eliza (2015) that the workforce has a statistically significant coefficient and positive in influencing economic growth. This means that this study's results are following the theory and previous research that has been previously proposed.

\section{Most Dominant Variable Influence on Economic Growth}

Based on the calculation findings in this report, the education variable is the most dominant effect on economic development since the education variable has the highest coefficient value of 0.913 compared to other variables. The education variable can become the most dominant variable, inseparable from education as one of the most critical aspects to improve the quality of human resources. Because through education, a person's thinking skills and abilities will increase and, in the end, can increase his productivity. Education is a development investment whose results can be enjoyed in the future. This shows that education is the key or access to a country's progress, including in the regions later, both economically and socially.

Todaro \& Smith (2006) believe that education plays a significant role in influencing a region's ability to integrate new technologies and develop manufacturing capability to achieve long-term growth and development. This 
study's findings are based on a new economic theory (new growth theory or endogenous growth theory) by Robert Solow. Human capital is a central element in this philosophy, and it is regarded as the engine of development. This shows that high-quality human resources will increase national output and income, where the quality of education will provide many benefits in accelerating economic growth.

\section{CONCLUSION}

According to the discussion findings, the level of education, the level of health, and the population all contribute positively to West Java Province's economy, and the level of education is the most critical factor influencing West Java's economic development. In this report, limited data from the measure of Human Capital is an obstacle. More representative data should be found in research and accounted for in an economic review.

\section{REFERENCES}

1. Amann, E., Aslanidis, N., Nixson, F., \& Walters, B. (2006). Economic Growth And Poverty Alleviation: A reconsideration of Dollar and Kraay. The European Journal of Development Research, 18(1), 22-44.

2. Asiedu, E. (2014). Does Foreign Aid in Education Promote Economic Growth? Evidence from Sub-Saharan Africa. Journal of African Development, 16(1), 37-59.

3. Becker, G. S. (2009). Human Capital: A Theoretical and Empirical Analysis, with Special Reference to Education. University of Chicago Press.

4. Camacho, M., Perez-Quiros, G., \& Poncela, P. (2015). Extracting Nonlinear Signals from Several Economic Indicators. Journal of Applied Econometrics, 30(7), 1073-1089.

5. Dwi-Atmanti, H. (2005). Investasi Sumber Daya Manusia Melalui Pendidikan. Jurnal Dinamika Pembangunan (JDP), 2(Nomor 1), 30-39.

6. Eliza, Y. (2015). Pengaruh Investasi, Angkatan Kerja dan Pengeluaran Pemerintah terhadap Pertumbuhan Ekonomi di Sumatera Barat. PEKBIS (Jurnal Pendidikan Ekonomi Dan Bisnis), 7(3), 198-208.

7. Fleisher, B., Li, H., \& Zhao, M. Q. (2010). Human Capital, Economic Growth, and Regional Inequality in China. Journal of Development Economics, 92(2), 215-231.

8. Handayani, N. S., Bendesa, I., \& Yuliarmi, N. (2016). Pengaruh Jumlah Penduduk, Angka Harapan Hidup, Rata-Rata Lama Sekolah, dan PDRB Per Kapita Terhadap Pertumbuhan Ekonomi di Provinsi Bali. Jurnal Ekonomi dan Bisnis Universitas Udayana, 5(10), 3449-3474.

9. Hanushek, E. A. (2013). Economic Growth in Developing Countries: The Role of Human Capital. Economics of Education Review, 37, 204-212.

10. Kumar, C. S. (2006). Human Capital and Growth Empirics. The Journal of Developing Areas, 153-179.

11. Martono, N. (2010). Metode Penelitian Kuantitatif: Analisis Isi dan Analisis Data Sekunder (sampel halaman gratis). RajaGrafindo Persada. 
12. Putri, R. F. (2015). Analisis Pengaruh Inflasi, Pertumbuhan Ekonomi dan Upah Terhadap Pengangguran Terdidik. Economics Development Analysis Journal, 4(2), 175-181.

13. Solow, R. M. (1956). A Contribution to the Theory of Economic Growth. The Quarterly Journal of Economics, 70(1), 65-94.

14. Spengler, J. J. (1977). Adam Smith on Human Capital. The American Economic Review, 67(1), 32-36.

15. Sugiyono. (2011). Metode Penelitian Kuantitatif, Kualitatif dan RED. Bandung: Afabeta.

16. Suhendra, I., \& Wicaksono, B. H. (2020). Tingkat Pendidikan, Upah, Inflasi, dan Pertumbuhan Ekonomi Terhadap Pengangguran di Indonesia. Jurnal Ekonomi$Q u, 6(1)$.

17. Tjiptoherijanto, P. (2001). Proyeksi Penduduk, Angkatan Kerja, Tenaga Kerja, dan Peran Serikat Pekerja dalam Peningkatan Kesejahteraan. Majalah Perencanaan Pembangunan, 23, 1-10.

18. Todaro, M. P., \& Smith, S. C. (2006). Pembangunan Ekonomi Jilid 1 Edisi Kesembilan. Jakarta: Erlangga.

19. Umiyati, E. (2014). Analisa Pertumbuhan Ekonomi Dan Ketimpangan Pembangunan Antar Wilayah di Pulau Sumatera.Jurnal Paradigma Ekonomika, 9(2).

20. Woodhall, M. (1987). Human Capital Concepts. Economics of Education (pp. 2124). 